\title{
Abstracts of Papers Presented at the Annual Meeting
}

\author{
SESSION 1A: LABOR MARKETS IN TIME AND SPACE
}

\begin{abstract}
Mothers, Wives, and Workers: The Dynamics of White Fertility, Marriage, and Women's Labor Supply in the United States, 1870-1930
\end{abstract}

The 1870-1930 period was a time when the patterns of women's labor supply and marriage changed profoundly. While fertility kept falling throughout the period, the nuptiality first declined, then, around 1900, picked up again. At the same time, American women were a growing presence on the labor market: first as singles, then, after 1900 , increasingly as married women. I develop a model which jointly explains labor market and marriage and fertility behavior during this period. Technological change and the associated increase in single women's labor supply are modeled as the prime force for change: they strengthened women's bargaining position on the marriage market. As a result, marriage rate declines first, as men try to resist the growing bargaining power of women, but ultimately increases, as men give in to it. The shape of marriage is changed in the process: the share of family budget controlled by women and married women's labor supply both increased.

THOMAS CVRCEK, Vanderbilt University

\section{From Coeds to Careers: Social Norms and the Unexpected Transformation of Women's Higher Education}

In the late 1960s and early 1970s the gender divide in American higher education narrowed rapidly as women abandoned the homemaking role and began to prepare for careers. The paper offers an explanation of why we might expect to see unexpected and rapid rather than gradual change in women's role in higher education. The dynamic social norms hypothesis developed here draws upon a theory of social change developed by Timur Kuran that predicts revolutionary rather than incremental shifts in social norms. Critical to the argument is the claim that in some settings, the choices of individuals are shaped in part by the choices of others. In the presence of interdependencies, the potential exists for rapid transformations such as that occurring in higher education between 1965 and 1980. Dramatic events such as the Civil Rights movement and the development of the birth control pill appear in the model as triggers of revolutionary change, but the potential for revolution arises from the slow undermining of social norms by economic forces.

STACEY JONES, University of Seattle

\section{Spatial Relations in U.S. Strike Activity, 1881-1894}

We move away from analyzing strikes as isolated, firm-level phenomenon and instead look at the connections among firms across space and time in 13 U.S. states from 1881 to 1894 . We informally develop six theories of connections among firms that could lead to correlations in strike activity. These avoid Hick's paradox, the major stumbling block for theories of strikes. Using rich data on the set of strikes in this period, we find strong correlation in the timing of strikes within and across states, con- 
sistent with some dependence in the underlying processes generating strikes at different firms. We find mixed evidence of localization.

JAMES ROBERTS, Northwestern University, and AARON SOJOURNER, Northwestern University

\section{Are Your Labor Standards Set in China? Evidence from the First Great Wave of Globalization, 1870-1914}

If there is a relation between trade and labor standards, it ought to turn up during the first wave of globalization. Between 1870 and 1914, the world moved from unregulated to regulated labor markets and levels of trade openness rose. In this paper, bringing together new international data sets on labor regulations and social entitlements, and bilateral trade data, we ask whether labor standards affected exports adversely. We find no particularly strong evidence that labor standards had long-term and enduring effects on trade, although in the short run more protective labor regulation lowered exports. Confronted with the new reality of regulated labor markets, firms adjusted the capital to labor mix.

Michael Huberman, Université de Montréal, and CHRISTOPHER M. MEISSNER, University of Cambridge

\section{SESSION 1B: CLASS AND RACE IN TIME AND SPACE}

\section{Flight from the City: The Role of Suburban Political Autonomy and Public Goods}

Why did white households relocate to the suburbs in response to black in-migration, despite the abundance of all-white neighborhoods within segregated cities? In the suburbs, residents could avoid sending their children to diverse public schools and compromising with a diverse electorate on taxes and expenditures. I explore the marginal willingness to pay for political distance by contrasting housing prices on either side of city-suburban borders from 1960 to 1980 . Identification arises from the fact that the local electorate or school system changes discretely at these borders, while housing and neighborhood quality shift more continuously. Throughout the period, homeowners disliked living in jurisdictions with poor residents, in part due to higher property taxes. The salience of race per se increased in the 1960s, and was associated with the incidence of race-related riot activity. Housing prices also responded to court-ordered desegregation plans in the 1970 s, particularly to forced bussing and school reassignment.

Leah Platt Boustan, University of California, Los Angeles

\section{The Economic Aftermath of the 1960s Riots: Evidence from Property Values}

In the 1960s many American cities experienced violent, race-related civil disturbances. Although social scientists have long studied the causes of the riots, the consequences have received much less attention. This paper examines census data from 1950 to 1980 to measure the riots' impact on the value of central-city residential property, and especially on black-owned property. Both ordinary least squares and instrumental variables estimates indicate that the riots depressed the median value of black- 
owned property between 1960 and 1970, with little or no rebound in the 1970s. A counterfactual calculation suggests about a 10 percent loss in the total value of blackowned residential property in urban areas. Analysis of household-level data reveals that the racial gap in property values widened in riot-afflicted cities during the 1970s. Census tract data for a small sample of cities suggest relative losses of population and property value in tracts that were directly affected by riots compared to other tracts in the same cities.

WILLIAM J. COLLINS, Vanderbilt University and NBER, and ROBERT A. MARGO, Boston University and NBER

\section{School Desegregation, School Choice, and Urban Population Decentralization}

Between 1960 and 2000, the aggregate fraction of large metropolitan area populations living in central cities declined from 0.42 to 0.30 . Further, while the aggregate nonblack population in central cities grew by only 1 percent between 1960 and 2000, the aggregate central city black population grew by 65 percent over this period. This paper examines the role of central city school desegregation in determining patterns of urban population decentralization by race. I empirically evaluate the responses of public and private school enrollment and location choices by race as a result of public school desegregation orders using census tract data over time and data from Welch \& Light (1987) and Logan (forthcoming) on central city school desegregation orders. Preliminary results exhibit evidence of a relationship between school desegregation and patterns in urban population decentralization.

NATHANIAL BAUM-SNOW, Brown University and NBER

Spatial and Social Dynamics of Rentier Capital in an Industrializing Town: The Case of Nineteenth-Century Montreal

This paper challenges the assumed primacy of external factors in the economic history of nineteenth-century Montréal, the first colonial town to industrialize. It links complete databases of properties in the town at six points over the century to GIS versions of historical maps. The analysis reveals a real-estate market characterized by very high turnovers in both properties and owners, alongside a remarkable level of continuity over time. Through a study of the strategies of rentier capital families over the entire nineteenth century, the paper examines how the decisions of the several hundred families who controlled the bulk of the city's housing stock influenced ethnic and social segregation and limited public education. By focusing on the rentier families whose continuous presence was a key element structuring this world in flux, this paper highlights how internal factors structuring the city's spatial evolution shaped the very real constraints Montrealers faced.

ROBERT C. H. SwEENy, Memorial University of Newfoundland

\section{PLENARY SESSION A: WHAT REMAINS AFTER FIFTY YEARS: A LOOK BACK AT DOMESTIC ECONOMIC POLICY IN THE DECADE AFTER SPUTNIK.}

The decade following Sputnik saw the development and then the decline of great optimism regarding the ability of policy, guided by economic expertise, to deal with major problems, notably economic stability and persistent poverty in a generally afflu- 
ent society. One effect was to afford economists, in particular, greater prestige and opportunities than before or since. The theoretical consensus and bold policies typified by the Kennedy tax cuts and Johnson Great Society were challenged by painful realities and by strong attacks on the underlying economic thinking. Today it can be argued that the neoclassical orthodoxy, which took over, has itself been carried too far and has produced serious imbalances. A re-examination is therefore in order, perhaps working toward a revival of the somewhat faded role of economics and economists in public discourse.

\section{Moderator, PAul M. HoHENBERG, Rensselaer Polytechnic Institute (Emeritus) Panelists, Michael A. Bernstein, University of California, San Diego, and CHRISTINA D. ROMER, University of California, Berkeley}

\section{SESSION 2A: LOCATION, LOCATION, AND WELL-BEING}

\section{Land of Milk and Butter: The Economic Origins of Cleanliness in the Dutch Golden Age}

This paper explains why early modern Holland, and particularly its women, had an international reputation for cleanliness. It was not the humid climate, or a Calvinistic obligation to toil and purify the soul, but the commercialization of dairy farming that led to improvements in household hygiene. In the fourteenth century peasants, but also urban dwellers, began to produce large quantities of butter and cheese for the market. In their small production units the wives and daughters worked to secure a clean environment for proper curdling and churning. We estimate that by 1500 half of all households in Holland produced butter and cheese. Their numbers declined when larger farms were set up in the sixteenth and seventeenth century, but the need to clean the dairy farms remained. At the same time, the migration of entire peasant families to towns, the hiring of farmers' daughters as maids, and the exceptionally high consumption of dairy continued to feed into the habit of regular cleaning in urban households.

BAS VAN BAVEL, University of Utrecht, and OSCAR GELDERBLOM, University of Utrecht

\section{Survival in Nineteenth-Century Cities: The Larger the City, the Smaller Your Chances}

This paper explores differences in the survival rates of Union Army veterans across cities and rural areas. We divide cities and rural areas according to population size. Survival rates in larger cities were considerably below those in smaller cities, which in turn were considerably below those in rural areas. The die-off rate among foreign-born veterans was exceptionally high, and this exacerbates the urban-rural disparity. We examine the urban size penalty (and the downward trend in that penalty) by assembling panel data assembled from the 100 largest American cities in 1860. The urban size penalty is then estimated by regressing the survival rate for each city against that city's rank/population and variables that control for socioeconomic characteristics (e.g., assessed valuation, household wealth, population density) and environmental factors (e.g., mortality rates, malaria prevalence, topography, existence of a sanitation system).

LOUIS P. CAIN, Loyola University Chicago, Northwestern University, and Center for Population Economics, and SoK Chul Hong, University of Chicago and Center for Population Economics 
More than half a century after it began, the ultimate causes of the baby boom remain a subject of scholarly debate. A recent article by Greenwood, Seshadri, and Vandenbrouke (2005) argues that technological progress in the household may have spurred this 20 -year increase in the fertility rate. Using evidence from newly compiled, county-level data with information on appliance diffusion and childbearing outcomes in the United States from 1940 to 1960 and state-level information on electrification and completed fertility from 1925 to 1960 , we find that the diffusion of technology and electricity is associated with declining (not increasing) fertility. Furthermore, we find that the Amish, a group much less affected by household electrification, had a baby boom. These results suggest that Greenwood et al.'s hypothesis for the baby boom is inconsistent with the empirical evidence.

MARTHA J. BAILEY, University of Michigan and NBER, and WILLIAM J. COLLINS, Vanderbilt University and NBER

\section{SESSION 2B: EXTRACTIVE EXPORTS AND SOUTH AMERICA IN TRANSITION}

\section{Guano, Credible Commitments, and State Finances in Nineteenth-Century Peru}

A main result in the literature on credible commitments and sovereign finance in the modern period is that financial credibility and political stability go hand-in-hand. Peruvian public finance in the nineteenth century is an exception. This paper explains how, in spite of Peru's chronic political instability, a web of self-enforcing contracts linking government revenues to debt service made the establishment of credible contractual relations with foreign interests possible. Overall the paper demonstrates that a sufficiently large penalty for default can produce an equilibrium with positive lending, even in highly unstable polities.

CATALIna VIZCARRA, University of Vermont

Fertilizer, Fiscal Crises, and the War of the Pacific

As a result of the War of the Pacific (1879-1884), Chile acquired large parts of Peru and Bolivia that contained valuable mineral deposits, especially nitrates. In this paper we estimate the gains and losses to Chile, Bolivia, and Peru of the changing jurisdiction of the nitrate deposits of the Atacama Desert. By seizing Peruvian and Bolivian deposits, Chile obtained a worldwide monopoly on this natural fertilizer. Before 1920 the Chilean government funded up to two-thirds of its expenditures through a tax on nitrate exports. Conquest thus not only brought with it substantial mineral wealth, but also enhanced the deposits' value by conferring market power to their sole owner. We construct estimates of government revenues from the nitrate deposits under the counterfactual supposition that the prewar boundaries were maintained. Chile's gains before 1890 were almost entirely at the expense of Peru, but later increases were increasingly at the expense of Bolivia.

RICHARD SICOTTE, University of Vermont, CATALINA VIZCARRA, University of Vermont, and KIRSTEN WANDSCHNEIDER, Middlebury College 


\section{Mineral Rights and Industrialization: Iron Ore and the Brazilian State in the Twentieth Century}

This paper analyzes the case of Brazil during the middle of the twentieth century to understand the manipulation of two institutions that have been important (though under-studied) for the processes of large-scale industrialization. First, sovereignty over mineral resources returned to the public domain, after a 40 -year experiment with privately held mineral rights. Secondly, the state transformed and vastly expanded its role within the economy to enter into the productive sectors as the owner of major iron-ore mining and basic steel enterprises. Ties of equity partnership bound the state to "downstream" producers of specialty iron and steel, as well as other capital goods enterprises. At the same time, sovereign debt obligation motivated the state to expand iron ore exports, as a source of revenues to service the debt. These conditions created credible commitments for the development of large-scale basic metallurgy, which allowed for increasingly secure investment in specialty capital goods industries.

GAIL D. TRINER, Rutgers University

\section{SESSION 2C: CONQUERING DISTANCE}

\section{What's Space Got to Do with It? Distance and Agricultural Productivity Before the Railway Age}

Owing to the high cost of transporting farm produce before the railway age, the land-intensiveness of European mixed farming caused both production and consumption of foodstuffs and intermediate farm inputs in the steady state to be highly dispersed, a spatial configuration offering weak inducement to reorganize farm structure or to invest available labor and capital with a view to increasing output. In such conditions the most common cause of rising agricultural productivity was spatial concentration of demand, which raised the demand price of farm produce and farm inputs within the privileged space bounded by discontinuities in the cost of land transport. The ultimate cause of observed changes in agricultural productivity before the nineteenth century must therefore be sought outside the farming sector in the development of markets for tradable manufactures, tradable services, and the economies of scale in their provision that supported spatial concentration of population.

GeORGe Grantham, McGill University

Lancashire, India, and Shifting Competitive Advantage in Cotton Textiles, 1700-1850: The Neglected Role of Factor Prices

We trace through the neglected role of factor prices in the shift of competitive advantage between Britain and India in cotton textiles between 1700 and 1850. In the early eighteenth century, wages in Britain were more than four times as high as in India, the world's major exporter of cotton textiles. This induced the adoption of more capital-intensive production methods in Britain and a faster rate of technological progress, so that competitive advantage had begun to shift in Britain's favor by the late eighteenth century. However, the completion of the process was delayed until after the Napoleonic Wars by increasing raw cotton costs, before supply adjusted to the major increase in demand for inputs. The neglect of factor prices in this context is surprising 
given their central role in the history of Anglo-American industrial development during the nineteenth century.

STEPHEN BROADBERRY, University of Warwick, and BISHNUPRIYA GUPTA, University of Warwick

\section{Transport Improvements, Agglomeration Economies and City Productivity: From When Did Transport Improvements Raise British Wages?}

"New economic geography" finds that the city agglomeration productivity effect comes not only from the size of the city itself, but from the size of its hinterland. Firms in the city are easily able to talk to suppliers, customers, and other firms in the hinterland, improving their information set and decision making, whilst those who live in the hinterland can commute to the city, so contributing to agglomeration economies. The nineteenth century saw the rise first of railways and then of trams, allowing such activities to occur for the first time. Did this lead to a rise in productivity? We find that the size of a city's hinterland had no effect on productivity in the nineteenth century. The cost of train travel, relative to earnings, remained high. But by the first decade of the twentieth century things had changed: train fares fell significantly relative to earnings, and convenient and very-low-cost trams became common. The productivity effect was real, but lower than is found in Britain today, probably reflecting the relative fall in the time, money, and discomfort cost of travel in the last 100 years. Nevertheless, we estimate that agglomeration economies raised urban wages by around 14 percent, and GDP in England and Wales by around 8 percent. This is in addition to earlier social savings estimates, and implies that railways and trams were worth around 14 percent of GDP by 1906 .

NichOLAS CRAFTS, Warwick University, and Timothy LeUnig, London School of Economics

\section{SESSION 3A: THINKING ABOUT BOOKS}

\section{Book Trade and Industrial Organization in Federal America}

One of Benjamin Franklin's most interesting business innovations was his system of contractual printing partnerships, by which he provided equipment and capital to set up offices in cities from New York to Antigua. In 1788 the Worcester, Massachusetts printer Isaiah Thomas traveled to Philadelphia to meet Franklin, there to learn the secret of his system. Thomas began to apply a variant in his enterprise and soon built up the largest bookselling network of the Federal period. But Franklin's system was apparently successful, Thomas's a costly failure. This paper contrasts the two and relates the different outcomes to changes in the publishing trade between the 1740s and the early 1800s. It will also contrast Thomas's business, organized around contractual relations, with that of the other main book publisher of his time, Mathew Carey of Philadelphia, who relied on reciprocally cooperative relations with other printers and booksellers on an ad hoc basis. 


\section{Book Distribution in Late Nineteenth Century America}

This paper concerns book distribution during the nineteenth century. I will argue that during the middle decades of that century a system of trade book distribution was established that endured for over a century and is only now being reshaped. I will explore the rise of trade sales - the regular auction sales of books held in the centers of production that were strictly restricted to the trade and that served to bring the trade together - and their replacement by dedicated jobbers and traveling salesmen that represented both publishers and wholesalers. Particular attention will be paid to the role of jobbers: the American News Company, Baker \& Taylor, J. B. Lippincott \& Co., and A. C. McClurg. In conclusion, I will briefly suggest the reasons why this system survived so long and how it has adapted to the relatively recent emergence of electronic information systems.

MiCHAEL WINSHIP, University of Texas at Austin

\section{The Book-of-the-Month Club: A Reconsideration}

American publishing over the past two centuries has predominantly been a make-to-stock business. The ability to manage inventories has been key to profitability. The bricks-and-mortar system dominating the whole channel of book distribution made this problematic, at least until very recently, all along the channel. The Book-of-the-Month Club represents in this context an innovative business model of great interest and a much-studied but grossly misunderstood act of entrepreneurship. Most of the academic literature about the Book-of-the-Month Club is written by Cultural Studies academics and concerns the development of twentieth-century American middle-class culture. This paper brings the company's strategic and business history into better focus, reconstructing the entrepreneurial context, the economic logic, the venture's resources and mobilization, and the evolving results. Issues arising have striking contemporary resonance (in understanding, for example, the history and significance of the conspicuous Amazon.com and also broader developments in the distribution sector of the modern economy.)

DANIEL RAFF, University of Pennsylvania

\section{SESSION 3B: GLOBALIZATION AND GEOGRAPHY}

\section{Pre-Industrial Inequalities: An Early Conjectural Map}

Drawing on new estimated income distributions for over a dozen early settings, this paper suggests that: Income inequality must have risen in earlier millennia; and Inequality could not have reached its historic peaks until there was sufficient surplus to sustain it. Two kinds of intranational inequality have been dropping over the millennia in which average incomes have risen. One is the share of potential inequality of income that is actually realized by those at the top. The other is length-of-life inequality, though it did not drop until after about 1750 . Some countries have experienced a drop in income inequality since the nineteenth century, while others have not. Most historical movements in income inequality have been driven by movements in the share of income captured by the top 1 percent relative 
to everybody else, and not by movements in the gap between the middle and bottom income classes.

PETER H. LINDERT, University of California, Davis, BRANKO MiLANOVIC, World Bank, and JEFFREY G. WILLIAMSON, Harvard University

\section{Where Did European Banks Go During the First Globalization? An Augmented Gravitational Approach to the Spatial Distribution of Multinational Banking}

The multinational expansion of European banks was a critical aspect of the first globalization. Why did they move and where did they go? This paper, based on a unique panel data set covering the foreign branches of European banks in a sample of up to 35 potential host countries, adopts an augmented gravity approach in order empirically to investigate the role of geography, institutions, and economic integration in banks' decisions to expand abroad. The model is estimated at micro-level for banks and banking places, and controls for the impact of host-country informational development, colonial links, trade and capital flows, spatial variables, and clustering effects due to increasing returns from externalities. The paper aims not only to provide a better understanding of the "fundamentals" driving banks' international expansion before World War I, but also to enhance comparisons with recent studies of late-twentiethcentury international banking and emphasize spatial similarities and differences with the recent wave of financial globalization.

Stefano Battilossi, Universidad Carlos III de Madrid

Globalization and the Geography of Urbanization in the Resource Rich Tropics before World War II

This paper uses panel data analysis to investigate urbanization in a particular group of tropical countries. Why between the late nineteenth century and World War II did a number of countries in Southeast Asia, South Asia, and West Africa, although highly globalized and experiencing rapid economic growth, retain an exceptionally low urbanization ratio but feature the emergence of a dominant or primate city? The paper argues that globalization associated with immobile natural resources and moving hinterland frontiers had a strong centripetal effect. These were only weakly counterbalanced by urban scale economies associated with the region's predominantly homemarket-based industrialization and the expanding administrative functions of governmental centers. Important in a spatial pattern of urban primacy were rapidly falling international shipping costs and mass international immigration.

GREGG HUFF, University of Glasgow

SESSION 3C: INVENTION, INNOVATION, AND INVESTMENT THROUGH SPACE AND TIME

Networks, Communal Knowledge, and the Location of Invention in Antebellum America

Invention varies greatly across space. In the nineteenth-century United States, invention concentrated by region and in cities. This paper argues that geographically 
specific networks were fundamental determinants of the distribution of knowledge and hence of the location of invention. In a study of 13 sectors of technology, 3,600 inventors, and 8,000 patents, I argue that networks of practitioners spread knowledge of technological problems and solutions, and such communal knowledge, largely occupationally grounded, structured invention. Because networks varied across space, so did invention. Technological occupations, including machinists, engineers, applied scientists, draftsmen, and patent agents, used widely applicable knowledge to invent across industry lines. Invention was particularly located where technological occupations congregated. For each technology, the share of inventions in such places exceeded their share of network practitioners. Because technological occupations were concentrated spatially, invention in many industries was concentrated in the same places, making them loci of invention.

Ross THOMSON, University of Vermont

Does Patenting Help to Diffuse Knowledge Spillovers? Evidence from the Geography of Nineteenth-Century Innovations

Modern patent laws are created to fulfill two functions: to encourage innovation and to facilitate the diffusion of technical knowledge. This paper uses new geographic data on the locations of nearly 5,000 nineteenth-century innovations to examine whether patents help to diffuse technical knowledge. It takes advantage of interindustry variation in the propensity to patent to examine whether the geographic localization of innovations is weaker in industries that patent more. The data show that innovations tend to be more geographically dispersed in patent-friendly industries. In contrast, innovations are strongly localized in industries where inventors rely on secrecy and other alternatives to patenting. To determine the direction of causality, the paper explores an exogenous shift in the propensity to patent on geographic concentration in chemicals. The data show that chemicals became less localized after patenting increased, even though chemical innovations became increasingly dependent on urban resources and geographic localization intensified across other sectors.

PETRA MOSER, Stanford University and NBER

\section{The Geography of Venture Capital Development in Postwar America}

This paper examines geographical heterogeneity in the emergence and development of venture capital institutions (VCs) in the United States since the mid-1940s. I argue that VCs are more likely to emerge in geographical areas with a significant agglomeration of individuals and institutions that engage in highly innovative activity. I assemble new estimates of venture capital activity by region between 1945 and 1980, and estimate the factors that predict the emergence of a regional venture capital industry. I also analyze the effects of geographical area and organizational form on the performance of VCs. The results provide new insights into the importance of geographical characteristics for the concentration of venture capital firms and for their success. These findings suggest that policies aimed at increasing the supply of venture capital to spur innovative activity are unlikely to succeed without concomitant investment in the underlying demand side factors that reach the necessary level of agglomeration. 


\section{PLENARY SESSION B: WHAT REMAINS AFTER 50 YEARS: THE ROLE OF ECONOMIC HISTORY AS A GUIDE TO ECONOMIC DEVELOPMENT}

During the post-Sputnik decade economic history flourished in part because it was seen as a guide to the then-salient issue of economic development in "underdeveloped" countries. Three scholars stand out in this regard: Alexander Gerschenkron, Simon Kuznets, and Walt W. Rostow. The link to development persuaded many departments to hire practitioners and require students to study economic history. Then or soon after, the influence of Annales and even Marxist thought also gave economic history a greater place within History. Both currents faded as other fashions and methodologies took over. Again, a re-examination is warranted, for instance by the rise of World History as a less "occicentric" approach to comparative performance, as well as by the contrasting recent experiences of Asian and other emerging economies.

Moderator, JAMES K. GALBRAITH, University of Texas at Austin Panelists, J. BRADFORD DELONG, University of California, Berkeley, and DICK EASTERLIN, University of Southern California

\section{SESSION 4A: MOBILITY AND INEQUALITY}

\section{Social Mobility Within and Across Generations in Britain Since 1851}

I use a rich data source to provide new measures of social mobility in England and Wales from 1851 to 1901 . Existing measures of intergenerational mobility derived from marriage registries fail to control for life-cycle differences between father and son. Correcting for this reveals significantly more mobility across generations than previous estimates: half of all sons reach a different occupational class than their father, and the rate of upward mobility is 40 percent greater than the rate of downward mobility. The data also allow the rate of intragenerational mobility to be measured for the first time. It is slightly lower than mobility across generations, but still substantial; 44 percent of males in their twenties changed occupational class over a 30 -year period. International and intertemporal comparisons show that mobility in Britain was much lower than in the United States, but that unlike in the United States, mobility increased from 1851 to 1970.

JASON LONG, Colby College

\section{The Roots of Regional Inequalities in Brazil, 1872-1920}

This paper provides historical perspectives on regional economic inequalities in Brazil. It analyzes the changes in the spatial concentration of economic activities based upon data on the municipal distribution of the labor force by occupation from the Censuses of 1872 and 1920. Minimum Comparable Areas were built in order to have consistent geographic area comparisons between censuses years. The New Economic Geography provides the analytical framework to show how geography, technology, and institutions combined give industrial preeminence to the city of São Paulo and why the accelerated industrial growth of São Paulo had such a limited and delayed effects in the rest of the country. Specialization indexes and Exploratory Spatial Data Analysis were applied to assess the fit of this explanation on the Brazilian experience between 1872 and 1920. 


\section{The Expansion of Public Schools and Decline in American Mobility}

The introduction of modern public education in early-twentieth-century America drastically altered geographical and financial constraints on educational access. However, the extent to which these constraints were relaxed, and the subsequent impact on labor market opportunities and welfare, varied across households of different incomes. This paper studies the evolution of public education and its influence on intergenerational income and occupational mobility. I construct a dataset of father-son pairs in Iowa at the turn of the century containing intergenerational income, occupation, location, and educational attainment information as well as detailed information on the spatial distribution of school types and quality. With these data, I estimate the elasticity of educational attainment with respect to school location, school quality, and parental income and combine these results with returns to schooling data and the spatial distribution of wealth to identify the effect of the geographical expansion of public education on intergenerational mobility.

JOHN PARMAN, Northwestern University

SESSION 4B: GLOBAL TRADE, EMPIRE, AND NINETEENTH-CENTURY MONEY

\section{International Trade in the Age of High Imperialism}

From independence to 1909 the United States formed 134 bilateral trade agreements and treaties with foreign nations. Some established unconditional most-favored-nation (MFN) relations, others conditional MFN, and yet others tariff preferences. The variety of trade arrangements offers an opportunity to investigate which forms of bilateralism were "progressive," or trade expanding; which ones were "pernicious," or trade destroying; which ones had no effect; and in any case, when and why any particular form of bilateralism was more likely to be obtained. Our empirical model allows us at once to distinguish among the effects of the different kinds of treaties and agreements and the varying effects over time of each kind. Conditional MFN treaties, in particular, were more progressive than would otherwise be estimated; but their progressiveness, as well as that of preferential treaties and agreements, eroded with age.

STEPHEN MEARDON, Williams College, and TREB AlLEN, Yale University

\section{Global Trade and the Maritime Transport Revolution}

What explains the growth of trade? And what is the role of transport improvements in globalization? We argue that the nineteenth century is the ideal testing ground: freight rates dropped by 40 percent while global trade increased 400 percent from 1870 to 1913 . We estimate the first indices of bilateral freight rates for the period and directly incorporate these into a standard gravity model. The results are striking as we find no evidence that the maritime transport revolution drove the late-nineteenthcentury global trade boom. Rather, the most powerful forces were those of income growth and convergence.

DAVID S. JACKS, Simon Fraser University, and KRISHNA PENDAKUR, Simon Fraser University 


\section{Trade and Empire}

Using a new database of over 21,000 bilateral trade observations for the period 1870-1913, this paper provides a quantitative assessment of the effect that empire had on trade as well as the channels through which colonial status impacted bilateral trade flows. Our augmented gravity model shows that belonging to an empire roughly doubled trade relative to those countries that were not part of an empire. The positive effect that empire exerts on trade does not appear sensitive to the identity of the core country or to inclusion of other institutional factors such as the monetary standard. The empirical analysis suggests that empires increased trade by lowering transactions costs and establishing policies promoting intra-empire trade. In particular, the use of a common language, the establishment of currency unions and the monetizing of recently acquired colonies, and preferential trade arrangements help to account for the observed boost in trade associated with empire.

KRIS JAMES MitCHENER, Santa Clara University and NBER, and MARC WEIDENMIER, Claremont McKenna College and NBER

\section{SESSION 5A: SPAIN THROUGH TIME: QUÉ PASA?}

\section{The Sustainable Debts of Philip II: Revenues, Expenditures and Borrowing Costs of the Spanish Crown, 1560-1598}

The defaults of Philip II have attained mythical status as the origin of sovereign debt crises. Three times during his reign the king failed to honor his debts and had to renegotiate borrowing contracts. Far from being fiscal disasters that reflected irrational spending policies and a hopeless fiscal position, we argue that Spanish debt in the sixteenth century was sustainable throughout. New evidence from primary records, combined with existing estimates, allows us to derive comprehensive estimates of debt and revenue. These show that primary fiscal surpluses were sufficient to repay the king's debts in most scenarios. We provide simulation evidence that shows that lending to the Spanish king was rational ex ante. These results are confirmed by estimating fiscal policy functions. In our view, these findings can explain the rapid and relatively painless re-schedulings that followed fiscal crises.

\section{MAURICIO DRELICHMAN, University of British Columbia and CIAR, and} HANS JOACHIM VoTH, Universitat Pompeu Fabra and CEPR

\section{The Dynamics of Rural-Urban Labor Markets in Spain, 1850-1930}

A major characteristic of the Spanish economy during the Restoration period was the slow reallocation of workers from "traditional" (agriculture) to "modern" sectors (industry and services). Employing an error-correction model, we find that wage changes in the cities had an economically significant and statistically robust positive effect on agrarian wages. Our estimates control for time as well as geography and take into account the endogeneity of labor supply and wages. We also find a significantly positive effect of urban labor demand shifts in rural labor markets using a modified shift-share analysis. In consequence, we conclude that the major culprit for slow structural change was urban labor demand because peasants were not reluctant to move and 
rural labor markets were fairly integrated with urban markets at regional and national level.

JOAN R. Roses, Universidad Carlos III de Madrid, and BLANCA SANCHEZ-Alonso, Universidad San Pablo - CEU

\section{Migrants and Market Potential in Spain over the Twentieth Century: A Test of the New Economic Geography}

This paper analyses the evolution in the explanatory power of a NEG model over different time periods corresponding to different stages in the economic development of Spain during the twentieth century: 1920s, 1960s, and 2000s. The contribution of this paper is two-fold. First, the long-term analysis allows us to undertake a comparison of periods characterized by the agglomeration and dispersion of economic activity. Second, this study focuses on an examination of migratory movements, a phenomenon that has been largely neglected by the literature of NEG. The results obtained show that emigrants have been attracted by economic agglomerations in each of the three periods analyzed. In other words, it has been shown that the presence of elements favoring agglomerations such as those proposed in the NEG literature were present both in the phases of concentration and in those of spatial redistribution of activity.

DANIEl A. TIRADO, University of Barcelona, JORDI PONS, University of Barcelona, ELISENDA PALUZIE, University of Barcelona, and JAVIER SILVESTRE, University of Zaragoza

\section{SESSION 5B: THE GREAT DEPRESSION ON THE MAP}

\section{Bargaining over a New Welfare State: A Model of the Regional Distribution of New Deal Funds}

We develop a theoretical model of bargaining in the U.S. Congress and apply it to the period of Franklin Roosevelt. The goal of the paper is to improve our understanding of the objectives behind the implementation of the New Deal. In the model, the distribution of federal funds across different regions of the country is the outcome of a bargaining game in which the President acts as the agenda-setter and Congress bargains over the shape of the spending bill. We then use the actual distributions for several New Deal programs to estimate the preference parameters of the Roosevelt administration. We link theory to data and estimate the model's parameters using a simple minimum distance approach. The results indicate that economic concerns for relief and recovery, though not necessarily for fundamental reform and development, largely drove the New Deal, and that political concerns mattered, but more on the margin.

KAJ ThOMSSON, Yale University, and AlESSANDRo BonatTi, Yale

Did Big Government's Largesse Help the Locals? The Implications of World War II Spending for Local Economic Activity, 1939-1958

We examine whether local economies that were the centers of federal spending on military mobilization experienced more rapid growth in consumer economic activity 
than other areas. We have combined information from a wide variety of sources into a data set that allows us to estimate a reduced-form relationship between retail sales per capita growth (1939-1948, 1939-1954, 1939-1958) and federal war spending per capita from 1940 through 1945. The results show that the World War II spending had virtually no effect on the growth rates in consumption that we examined. This contrasts with Fishback, Horrace, and Kantor's (2005) findings of about half a dollar increase in retail sales in 1939 associated with a dollar of New Deal public works and relief spending during the 1930s. Several factors contributed to this relative lack of impact. World War II spending often required a conversion of plants designed for civilian good production into military factories and back again over the nine-year period. Substantially higher federal tax rates that were paid by the majority of households imposed much stronger fiscal drags on the benefits of the spending. Finally, less of the military spending was earmarked for wages and use of locally produced inputs, which reduced the direct stimulus to the local economy.

JOSEPH CULlen, University of Arizona, and PRICE FISHBACK, University of Arizona

\section{The Spatial Character of the Housing Depression and Recovery in the 1930s}

The collapse and recovery of the residential housing sector in the 1930s is generally examined at the aggregate level even though underlying forces including overbuilding, uncontrolled land development, and mortgage lending distress had differential impacts across space. In this paper we characterize variations in the depth of the housing collapse and the speed of its recovery across regions, among cities of different size, and within the central city and suburban rings of metropolitan areas. We do so first by examining information drawn from published Census reports on the composition of the housing stock, the structure of the residential construction industry, homeownership rates, and institutional distribution of home mortgage debt. We then use regression analysis to characterize spatial variation in annual residential building permit series for 257 cities between 1921 and 1940 and homeownership patterns as measured by the 1920, 1930 and 1940 IPUMS.

Gray KimBrough, University of North Carolina, Greensboro, and KENNETH SNOWDEN, University of North Carolina, Greensboro 